\title{
STUDY ON PROTECTION OF CARDIOVASCULAR SYSTEM AND KIDNEY BY DIFFERENT ANGIOTENSIN RECEPTOR BLOCKERS IN EXPERIMENTALLY INDUCED HYPERTENSIVE ADULT MALE ALBINO RATS
}

\author{
Zaki Youssef Abdel kader, El Sayed Mohamed Kamel, Fatma Atwa Ali, \\ Sahar Kamal Younes Ali \\ Clinical Pharmacology Department, Faculty of Medicine, Zagazig University, Zagazig, Egypt \\ Corresponding author: \\ ABSTRACT
}

Sahar Kamal Younes Ali;

Tel.0201147593693;email:saharkamal81@yahoo.com

\section{Background: In treatment of hypertension, care should be taken for} preventing hypertensive organ injuries as well as lowering blood pressure to the adequate level in order to decrease the risk of cardiovascular and renal diseases. Objectives: To assess and compare the possible protective effect of various angiotensin receptor blockers namely candesartan, olmesartan, telmisartan , and valsaratn on cardiovascular and renal tissues in renal hypertensive rats Methods: In this study 72 adult male albino rats were used and divided into six equal groups (each of 12 rats): Group 1, control normal received the vehicle; Group 2, control renal hypertensive induced by left renal artery ligation received the vehicle and Group 3 treated renal hypertensive rats which is divided into four subgroups: subgroup (A) received candesartan ( $0.1 \mathrm{mg} / \mathrm{kg} /$ day); subgroup (B) received olmesartan ( $3 \mathrm{mg} / \mathrm{kg} /$ day ); subgroup (C) received telmisartan ( 0.5 $\mathrm{mg} / \mathrm{kg} / \mathrm{day}$ ), and subgroup (D) received valsartan $(0.5 \mathrm{mg} / \mathrm{kg} /$ day $)$. Rats received drugs orally by gavage once daily for 2 weeks. Results: The present study revealed that left renal artery ligation induced significant increases in mean arterial blood pressure (MABP), heart rate (HR), heart weight, cardiac fibrosis and glomerulosclerosis. Also, there were significant increases in serum level of tumor necrosis factor alpha (TNF- $\alpha$ ), cardiac level of inteleukin1 $\beta$ (IL1 $\beta$ ), and cardiac and renal levels of malondialdehyde (MDA) concomitant with significant reduction in cardiac and renal level of reduced glutathione (GSH). MABP was similarly reduced in candesartan, olmesartan, telmisartan and valsartan groups compared to control renal hypertensive group. Heart rate, cardiac weight, and cardiac fibrosis were significantly reduced in telmisartan and candesartan group. Telmisartan and candesartan suppressed serum level of TNF $\alpha$ and the cardiac level of IL-1 $\beta$. Meanwhile, olmesartan and valsartan significantly decreased glomerulosclerosis index and renal level of MDA with significant increase in renal level of GSH. Conclusion: Telmisartan and candesartan exerted better cardioprotective effect via prevention of inflammatory cascade, and olmesartan and valsartan exerted better renoprotective effect via enhancement of antioxidant capacity.

Key words: hypertension, angiotensin receptor blockers, candesartan, olmesartan, telmisartan, valsartan, TNF- $\alpha$, IL1 $\beta$, MDA and GSH.

\section{INTRODUCTION}

H ypertension (HTN) is a global disease burden and a major cause of worldwide morbidity and mortality ${ }^{[1]}$. HTN is a main risk factor for coronary heart disease, congestive heart failure, stroke, and renal failure ${ }^{[2]}$. The ideal goal of antihypertensive therapy is not only to normalize the blood pressure level but also to prevent end organ damage and the progression of cardiovascular disease $^{[3] .}$ The renin angiotensin aldosterone (RAAS) system plays an essential role in the pathogenesis of different clinical conditions including atherosclerosis, hypertension, left ventricular hypertrophy, myocardial infarction, and heart failure ${ }^{[4]}$ so; therefore the renin angiotensin aldosterone system represents a logic therapeutic target in the management of hypertension, renal and cardiovascular diseases ${ }^{[5]}$.

Angiotensin receptor blockers (ARBs) are well-tolerated and effective antihypertensive agents which block the harmful effects of angiotensin II at the angiotensin II type 1 
receptor (AT1) ${ }^{[6]}$.They have also beneficial effects on hypertension related cardiovascular and renal end organ damage beyond blood pressure lowering effect ${ }^{[7]}$. Oxidative stress and inflammation play a main essential role in the pathogenesis and development of hypertension and its complication ${ }^{[8]}$. Candesartan, olmesartan, telmisartan, and valsartan are angiotensin receptors blockers which are widely used in treatment of hypertension [9]. Among these ARBs, telmisartan and candesartan reduce inteleukin $1 \beta$ (IL-1 $\beta$ ) and tumor necrosis factor $\alpha(\mathrm{TNF} \alpha)$, and reversed adhesion molecular expression and macrophage accumulation ${ }^{[10]}$.

Telmisartan also has ability to activate peroxisome proliferator-activated receptorgamma (PPAR- $\gamma$ ), which leads to inhibition of the expression of inflammatory genes that affect endothelial function ${ }^{[11]}$. Olmesartan, and valsartan have been reported to modulate oxidative damage ${ }^{[11]}$.

The current study aimed to assess and compare the possible protective effect of some angiotensin receptor blockers namely candesartan, olmesartan, telmisartan, and valsaratn on cardiovascular and renal tissues in renal hypertensive rats elicited by left renal artery ligation.

\section{MATERIALS AND METHODS}

\section{Animals}

72 adult male albino rats weighing 150-200 $\mathrm{g}$ were used in the current study. Animals were obtained from the animal house of Faculty of medicine, Zagazig University, Egypt. Rats were allowed standard pellet diet and tap water ad libitum through the whole experimental period. They were kept at a constant temperature $\left(23 \pm 2^{\circ} \mathrm{C}\right)$, humidity (60 $\pm 10 \%)$ and a light/ dark (12 h:12 h) cycle. The animals were randomly assigned to experimental groups. All tests were performed between 8.00 and $15.00 \mathrm{~h}$. The experiment was performed in the pharmacology department, faculty of medicine, Zagazig University.

Experimental design and animal handling were performed in accordance with protocols approved by the local experimental ethics committee guidelines of the Egyptian Society of
Neuroscience, the Ethical Committee of the Faculty of Medicine, Zagazig University, for Animal Use and the guidelines of the US National Institutes of Health on animal care.

Drugs and chemicals:

Candesartan powder (AstraZeneca AB, Egypt license of AstraZeneca Sweden), telmisartan powder (Boehringer GMBH, Giza, Egypt), olmesartan powder (Apex multiapex for pharmaceutical industries, Bader city, Egypt) and valsartan powder (Novartis co., Egypt). All the previous drugs were freshly dissolved in distilled water prior to administration. Thiopental (sodium -thiopental) $1 \mathrm{gm}$ vials were obtained from Biochemic GMBH, Vienna, Austria, Ethyl Carbamate (Urethane) crystals (Prolapo, Paris), Heparin ampoules (5000 I.U. /ml) (Nile Co. for Medical industries, Egypt). Penicillin G vials were purchased from CID Co. for Medical industry, Egypt.

\section{Experimental protocol:}

The animals were divided into six equal groups ,12 rats each as following group 1: control normal group, group 2: control (untreated) renal hypertensive group + vehicle (distilled water),group 3: treated renal hypertensive group; which was further subdivided into four equal subgroups 12 rats each, subgroup (A) was given candesartan 0.1 $\mathrm{mg} / \mathrm{kg} / \mathrm{day}^{[12]}$, subgroup (B) was given olmesartan $3 \mathrm{mg} / \mathrm{kg} /$ day $^{[13]}$, $\operatorname{subgroup}(\mathrm{C})$ was given telmisartan $0.5 \mathrm{mg} / \mathrm{kg} / \mathrm{day}^{[14]}$ and subgroup (D) was given valsartan 0.5 $\mathrm{mg} / \mathrm{kg} / \mathrm{day}{ }^{[15]}$. All drugs and vehicles were given orally by gavage in the before mentioned doses for 2 weeks.

\section{Measurement of hemodynamic parameters:}

The systolic, diastolic, mean arterial blood pressure (MABP) and heart rate (HR) were recorded by noninvasive computerized tailcuff System) and the data were automatically analyzed and stored in a computer.

\section{Blood and tissue collection:}

At the end of the experiments, $2 \mathrm{ml}$ blood sample were obtained from retro-orbital plexus via rat arterial polyethylene cannula in heparinized tubes. The samples were centrifuged and serum was used for TNFestimation. Subsequently, after body weighting, rats were sacrificed and the heart \&kidney tissues were extracted and washed with ice-cold 
saline. After weighing the hearts, the heart and kidney tissues of each group were then divided into two subgroups. The tissues of first subgroup were fixed in $10 \%$ formalin and embedded in paraffin for histopathological studies, the remainder were washed with icecold saline, immersed immediately in liquid nitrogen and kept at $-80{ }^{\circ} \mathrm{C}$ and then homogenized in the appropriate buffer for estimation of IL-1 $\beta$,MDA and GSH.

Plasma level of tumor necrosis factor (TNF)- $\alpha$ was measured using commercial Rat Enzymelinked immunosorbent assay (ELISA) (TNF)- $\alpha$ kit according to the manufacturer's instructions. Estimation of interleukin $1 \beta$ (IL-1 $\beta$ ) was done using ELISA kit supplied by $R \& D$ system which employs the quantitative sandwich enzyme immunoassay technique. Tissue level of malondialdehyde (MDA) and GSH were measured Using Colorimetric Assay Kit according to the manufacturer's instructions.

\section{Histopathological studies:}

The excised wet heart was kept in formalin $(10 \%)$ and the mid ventricle sections were fixed then embedded in paraffin. left ventricular tissue sections stained with haematoxylin and eosin (H\&E) and Masson Trichrome stain (MT) . the fibrotic ratio was graded on a 5-point scale ranging from 0 to 4,0 (normal), 1 (minimal ) lesion extent between $10-25 \%$ of a transverse section), 2 (mild) (between 25-50\%), 3(moderate) (between 50-75\%), and 4 (severe) (exceeding $75 \%$ ) of the myocardium ${ }^{[16]}$.

Kidney sections which were stained with $H \& E$ observed under a light microscope in a blinded fashion. The glomerulosclerosis (GS) index was determined by a semi-quantitative method as forty glomeruli from each kidney were graded according to the severity of the glomerular damage ${ }^{[17]}$.

\section{Statistical analysis of the results:}

The obtained results were tabulated as means \pm SE. Comparison between different groups were made using one way analysis of variances (one-way ANOVA) followed by Post-Hoc (least significant difference "LSD") tests as described by Armitage and Berry [18]. The differences were considered to be significant when $\mathrm{p}<0.05$. Statistical Package of Social Sciences (SPSS) computer software (version 16) was used to carry out the statistical analysis.

\section{RESULTS}

\section{Physical measurement and heart weight:}

As shown in table (1) candesartan, olmesartan, telmisartan and valsartan produced significant $(\mathrm{p}<0.05)$ reduction in the systolic, diastolic and mean arterial blood pressure (MABP) as compared to control meanwhile the heart rate was significantly ( $\mathrm{p}$ $<0.05)$ decreased in candesartan and telmisartan treated groups by $25 \%$ and $36 \%$ in relation to control group however, olmesartan and valsartan had insignificant effect when compared to control group. Regarding heart weight, there was significant $(\mathrm{p}<0.05)$ reduction in candesartan and telmisartan treated group by $11 \%$ and $19 \%$ when compared to control group. Meanwhile insignificant changes were noticed in olmesartan and valsartan group in relation to control (figure 1).

Effect on cardiac histopathological architecture: Fig (2) and photo (1A, 1B)

The result of the present study showed that the ratio of cardiac fibrosis between all groups was significantly $(\mathrm{p}<0.05)$ reduced in candesartan, olmesartan, telmisaran and valsartan treated groups by $60 \%, 50 \%, 71 \%$, $28 \%$ respectively compared to control meanwhile telmisartan and candesartan showed prominent reduction more than the other previous groups.

\section{Effect on renal histopathological architecture:}

The elevated glomerulosclerosis index was significantly (p <0.05) reduced in olmesartan(52\%) and valsartan(41\%) treated group while, insignificant change was noticed in candesartan and telmisartan treated group when compared to control group (figure 3).

\section{Biochemical results:}

As shown in table (2), renal hypertension induced significant $(\mathrm{p}<0.05)$ elevation in serum level of $\mathrm{TNF} \alpha$ by $600 \%$. In contrast candesartan and telmisartan treated group showed significant $(p<0.05)$ reduction in serum level of TNFa by $45 \%$ and $63 \%$ while, olmesartan and valsartan showed insignificant changes in relation to control.

Regarding the effect of different ARBs used in this work, it was noticed that candesartan, olmesartan and telmisartan significantly ( $\mathrm{p}$ $<0.05$ ) reduced cardiac IL1 $\beta$ by $58 \%, 36 \%$, and $64 \%$, respectively while, valsartan 
produced insignificant effect on cardiac IL1 $\beta$. They also significantly $(\mathrm{p}<0.05)$ decreased the elevated cardiac MDA by $43 \%, 55 \%, 47 \%$ respectively, as compared to control. On the other hand, candesartan, olmesartan, telmisartan and valsartan showed insignificant effect on cardiac GSH as compared to control rats (table 3 ).

No differences were observed in renal IL1 $\beta$ neither between the control normal nor control renal hypertensive group and other treated groups.
Treatment

with

candesartan, olmesartan,telmisartan and valsartan was associated with significant reduction of renal level of MDA in relation to control rats by $32 \%, 60 \%, 53 \%, 57 \%$ respectively. Meanwhile, the decreased renal level of GSH was significantly $(\mathrm{p}<0.05)$ elevated in only olmesartan and valsartan treated group by $59 \%$ and $55 \%$ respectively (figure 4 ).

Table (1): Effect of candesartan $(0.1 \mathrm{mg} / \mathrm{kg})$, olmesartan $(3 \mathrm{mg} / \mathrm{kg})$, telmisartan $(0.5 \mathrm{mg} / \mathrm{kg})$ and valsartan $(0.5 \mathrm{mg} / \mathrm{kg})$ orally on systolic, diastolic and mean arterial blood pressure (MABP), and heart rate $(\mathrm{HR})$ in renal hypertensive rats.

\begin{tabular}{|c|c|c|c|c|c|c|}
\hline $\begin{array}{c}\text { Group } \\
\mathrm{n}=12\end{array}$ & $\begin{array}{c}\text { Control normal } \\
\text { group }\end{array}$ & $\begin{array}{l}\text { Control renal } \\
\text { hypertensive } \\
\text { group }\end{array}$ & $\begin{array}{c}\text { Candesartan } \\
\text { group } \\
(\mathbf{0 . 1} \mathbf{m g} / \mathbf{k g})\end{array}$ & $\begin{array}{c}\text { Olmesartan } \\
\text { group } \\
(3 \mathrm{mg} / \mathrm{kg})\end{array}$ & $\begin{array}{l}\text { Telmisartan } \\
\text { group } \\
(0.5 \mathrm{mg} / \mathrm{kg})\end{array}$ & $\begin{array}{l}\text { Valsartan group } \\
(0.5 \mathrm{mg} / \mathrm{kg})\end{array}$ \\
\hline $\begin{array}{c}\text { Systolic blood } \\
\text { pressure }(\mathrm{mmHg})\end{array}$ & $116 \pm 6.387^{A}$ & $160 \pm 6.064^{B}$ & $94 \pm 4.823^{A}$ & $99 \pm 3.266^{\mathrm{A}}$ & $101 \pm 9.525^{A}$ & $90 \pm 2.594^{\mathrm{A}}$ \\
\hline $\begin{array}{c}\text { diastolic blood } \\
\text { pressure }(\mathrm{mmHg})\end{array}$ & $99 \pm 6.387^{\mathrm{A}}$ & $107 \pm 3.454^{\mathrm{B}}$ & $89 \pm 5.530^{A}$ & $89 \pm 3.882^{A}$ & $87 \pm 7.775^{A}$ & $85 \pm 3.529^{A}$ \\
\hline $\mathrm{MABP}(\mathrm{mmHg})$ & $104+5.981^{\mathrm{A}}$ & $124 \pm 8.825^{\mathrm{B}}$ & $91 \pm 5.571^{\mathrm{A}}$ & $93 \pm 2.922^{\mathrm{A}}$ & $92 \pm 4.010^{\mathrm{A}}$ & $87 \pm 2.302^{\mathrm{A}}$ \\
\hline HR (beats/minute) & $279 \pm 6.531^{A}$ & $326 \pm 9.811^{B}$ & $245 \pm 6.715^{A}$ & $311 \pm 9.843^{B}$ & $208 \pm 3.071^{A}$ & $298 \pm 11.432^{B}$ \\
\hline
\end{tabular}

- Within the same row, values without the same superscript capital letter are significantly $(\mathrm{p}<0.05)$ different.

- $\mathrm{n}=$ number of animals

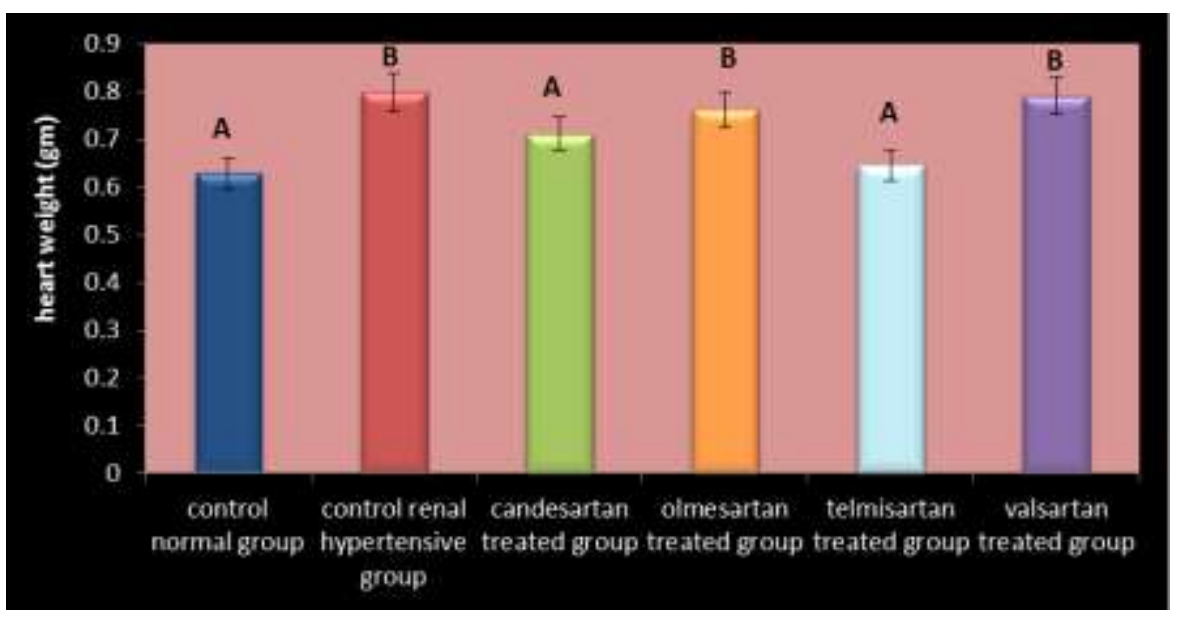

Figure (1): Effect of of candesartan $(0.1 \mathrm{mg} / \mathrm{kg})$, olmesartan $(3 \mathrm{mg} / \mathrm{kg})$, telmisartan $(0.5 \mathrm{mg} / \mathrm{kg})$ and valsartan $(0.5 \mathrm{mg} / \mathrm{kg})$ orally on heart weight in renal hypertensive rats. Values with different capital letters are significantly different $(p<0.05)$ 


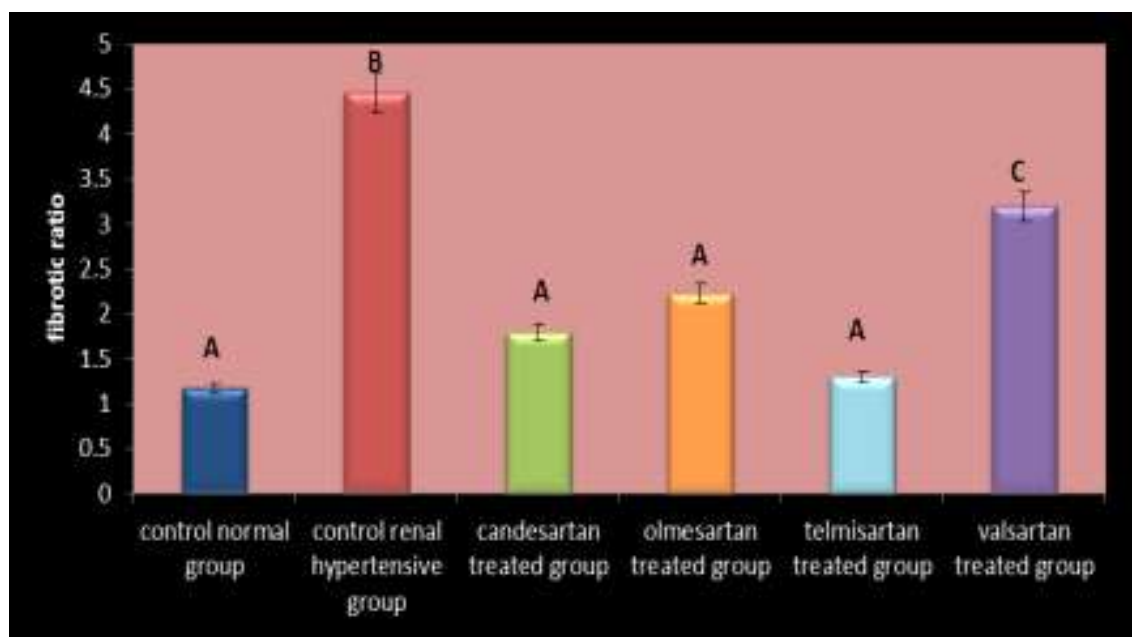

Figure (2): Effect of of candesartan $(0.1 \mathrm{mg} / \mathrm{kg})$, olmesartan $(3 \mathrm{mg} / \mathrm{kg})$, telmisartan $(0.5 \mathrm{mg} / \mathrm{kg})$ and valsartan $(0.5 \mathrm{mg} / \mathrm{kg})$ orally on cardiac fibrosis in renal hypertensive rats. Values with different capital letters are significantly different $(p<0.05)$
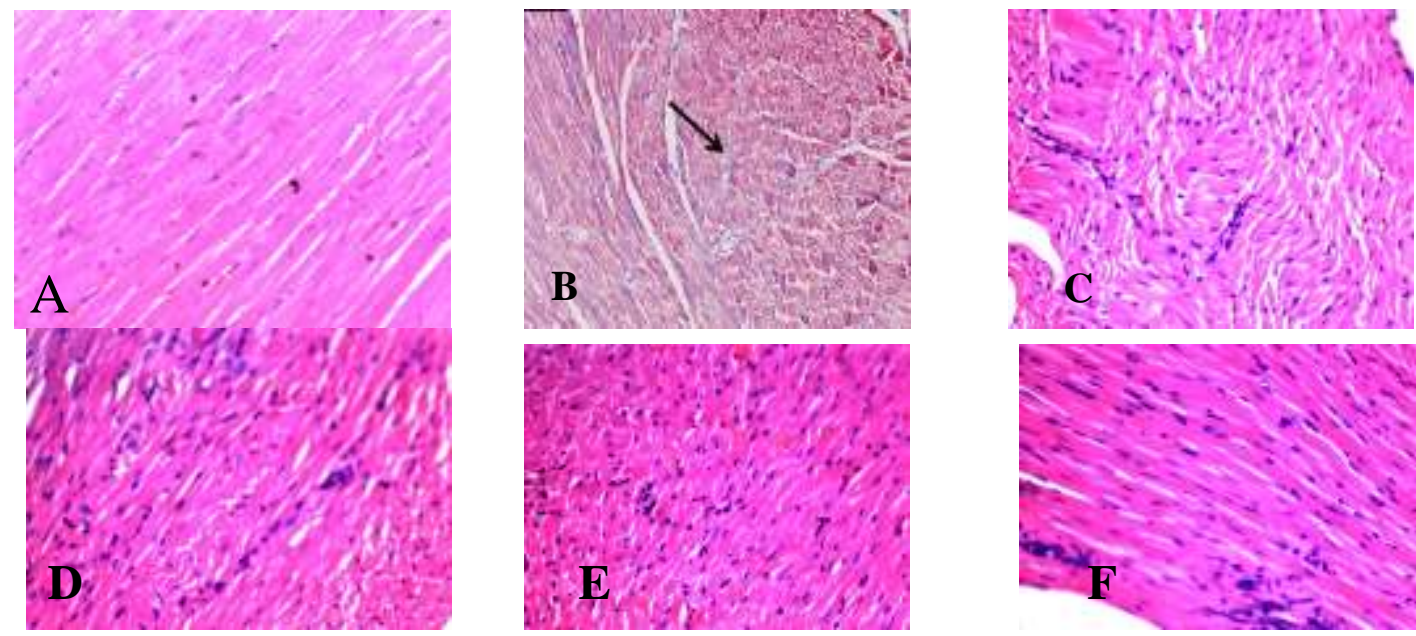

Photo (1A): cardiac fibrosis. Photomicrographs of cardiac sections stained with haematoxylin and eosin (H\&E) (x 400) in each group. (A) control normal group, (b)control renal hypertensive group, (c)candesartan treated group, (D)olmesartan treated group, (E)telmisartan treated group and (F)valsartan treated group.
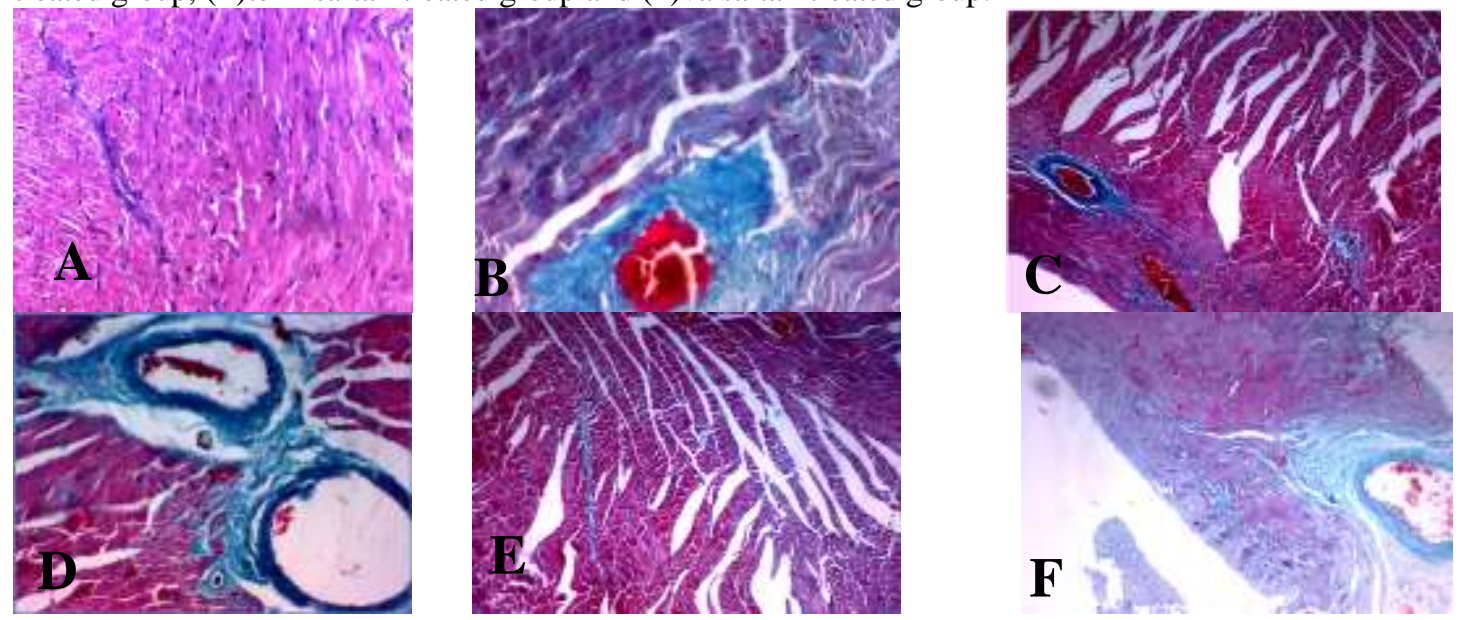

Photo (1B): cardiac fibrosis. Photomicrographs of cardiac sections stained with Massons Trichrome stain (MT) (x 400) in each group. (A) control normal group, (b)control renal hypertensive group, (c)candesartan treated group, (D)olmesartan treated group, (E)telmisartan treated group and (F)valsartan treated group. 


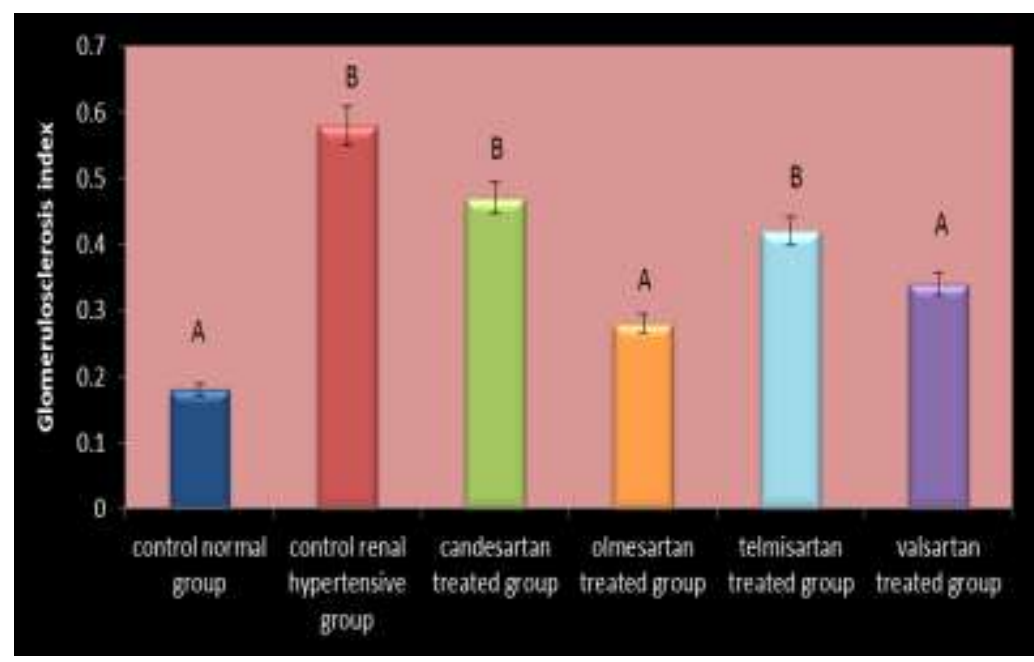

Figure (3): Effect of of candesartan $(0.1 \mathrm{mg} / \mathrm{kg})$, olmesartan $(3 \mathrm{mg} / \mathrm{kg})$, telmisartan $(0.5 \mathrm{mg} / \mathrm{kg})$ and valsartan $(0.5 \mathrm{mg} / \mathrm{kg})$ orally on degree of glomerulosclerosis in renal hypertensive rats. Values with different capital letters are significantly different $(\mathrm{p}<0.05)$

Table ( $(r)$ : Effect of of candesartan $(0.1 \mathrm{mg} / \mathrm{kg})$, olmesartan $(3 \mathrm{mg} / \mathrm{kg})$, telmisartan $(0.5 \mathrm{mg} / \mathrm{kg})$ and valsartan $(0.5 \mathrm{mg} / \mathrm{kg})$ orally on serum level of tumor necrosis factor $(\mathrm{TNF} \alpha)$ in renal hypertensive rats.

\begin{tabular}{|c|c|c|c|c|c|c|}
\hline $\begin{array}{r}\text { Group } \\
n=6 \\
\text { Parameter }\end{array}$ & $\begin{array}{c}\text { Control } \\
\text { normal group }\end{array}$ & $\begin{array}{c}\text { Control renal } \\
\text { hypertensive } \\
\text { group }\end{array}$ & $\begin{array}{c}\text { Candesartan } \\
\text { group } \\
(0.1 \mathrm{mg} / \mathrm{kg})\end{array}$ & $\begin{array}{c}\text { Olmesartan } \\
\text { group } \\
(3 \mathrm{mg} / \mathrm{kg})\end{array}$ & $\begin{array}{c}\text { Telmisartan group } \\
(0.5 \mathrm{mg} / \mathrm{kg})\end{array}$ & $\begin{array}{c}\text { Valsartan group } \\
(0.5 \mathrm{mg} / \mathrm{kg})\end{array}$ \\
\hline $\begin{array}{l}\text { tumor necrosis } \\
\text { factor }(\mathrm{TNF} \alpha) \\
(\mathrm{pg} / \mathrm{ml})\end{array}$ & $\underset{\mathrm{A}}{14.1 \pm 0.905}$ & $\underset{B}{98.2 \pm 0.74}$ & $\underset{\mathrm{C}}{54.7 \pm 0.321}$ & $\underset{B}{82.7 \pm 0.422}$ & $\underset{\mathrm{C}}{36.8 \pm 0.570}$ & $\underset{B}{87.5 \pm 0.973}$ \\
\hline
\end{tabular}

- Within the same row, values without the same superscript capital letter are significantly $(\mathrm{p}<0.05)$ different.

- $\quad \mathrm{n}=$ number of animals

Table ( $\left.{ }^{\top}\right)$ : Effect of of candesartan $(0.1 \mathrm{mg} / \mathrm{kg})$, olmesartan $(3 \mathrm{mg} / \mathrm{kg})$, telmisartan $(0.5 \mathrm{mg} / \mathrm{kg})$ and valsartan $(0.5 \mathrm{mg} / \mathrm{kg})$ orally on cardiac content of IL-1 $\beta$, malondialdehyde (MDA) and glutathione (GSH) in renal hypertensive rats.

\begin{tabular}{|c|c|c|c|c|c|c|}
\hline $\begin{array}{c}\text { Group } \\
n=6 \\
\text { Parametex }\end{array}$ & $\begin{array}{c}\text { Control } \\
\text { normal group }\end{array}$ & $\begin{array}{l}\text { Control renal } \\
\text { hypertensive } \\
\text { group }\end{array}$ & $\begin{array}{l}\text { Candesartan } \\
\text { group } \\
(0.1 \mathrm{mg} / \mathrm{kg})\end{array}$ & $\begin{array}{c}\text { Olmesartan group } \\
(3 \mathrm{mg} / \mathrm{kg})\end{array}$ & $\begin{array}{l}\text { Telmisartan } \\
\text { group } \\
(0.5 \mathrm{mg} / \mathrm{kg})\end{array}$ & $\begin{array}{l}\text { Valsartan group } \\
(0.5 \mathrm{mg} / \mathrm{kg})\end{array}$ \\
\hline $\begin{array}{c}\text { cardiac IL- } \\
1 \beta(\mathrm{pg} / \mathrm{ml} / \text { tissue })\end{array}$ & $31.38 \pm 1.4^{\mathrm{A}}$ & $91.13 \pm 4.9^{\mathrm{B}}$ & $38.152 .3^{A}$ & $58.37 \pm 3.4^{\mathrm{C}}$ & $33.50 \pm 2.2^{A}$ & $89.17 \pm 5.2^{B}$ \\
\hline $\begin{array}{c}\text { Cardiac } \\
\text { malondialdehyde } \\
\text { (MDA) content } \\
\end{array}$ & $48.99 \pm 4.40^{A}$ & $112.23 \pm 5.41^{\mathrm{B}}$ & $64.02 \pm 3.99^{A}$ & $51.02 \pm 3.79^{A}$ & $59.21 \pm 4.11^{A}$ & $94.3 \pm 5.02^{B}$ \\
\hline $\begin{array}{c}\text { Cardiac } \\
\text { glutathione (GSH) } \\
\text { content } \\
\end{array}$ & $98.2 \pm 3.67^{A}$ & $84.2 \pm 4.01^{B}$ & $90.7 \pm 4.84^{\mathrm{B}}$ & $87.2 \pm 3.04^{B}$ & $93.3 \pm 3.87^{\mathrm{B}}$ & $91.8 \pm 2.02^{\mathrm{B}}$ \\
\hline
\end{tabular}

- Within the same row, values without the same superscript capital letter are significantly $(\mathrm{p}<0.05)$ different.

- $\mathrm{n}=$ number of animals 


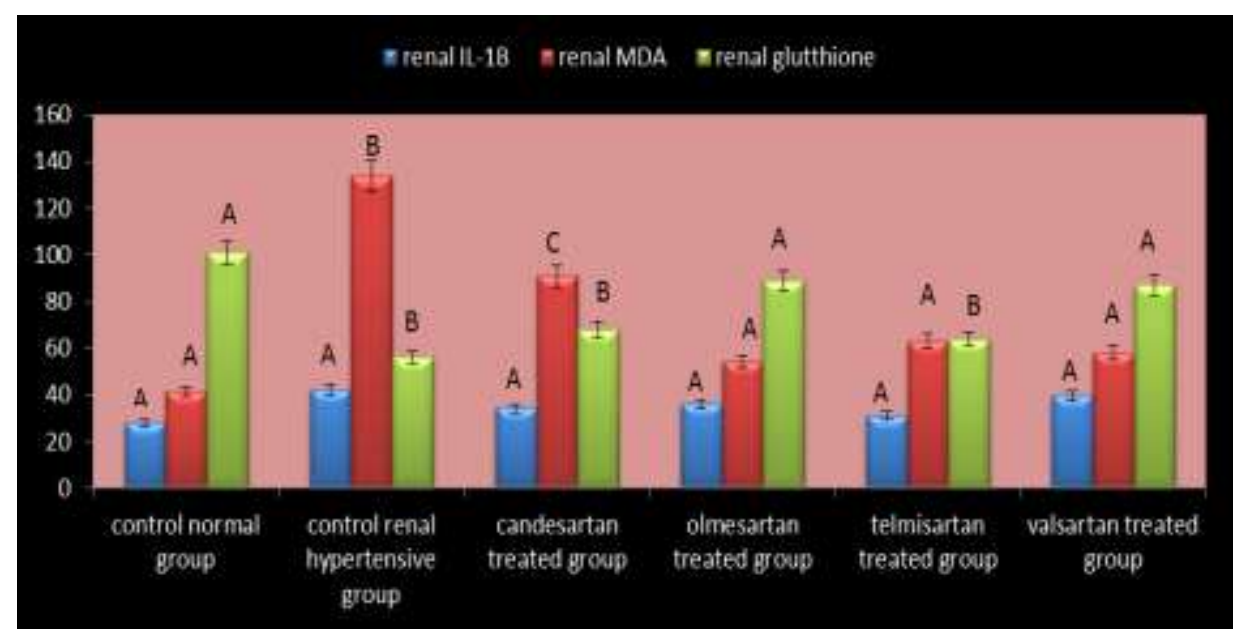

Figure ( $)$ : Effect of candesartan $(0.1 \mathrm{mg} / \mathrm{kg})$, olmesartan $(3 \mathrm{mg} / \mathrm{kg})$, telmisartan $(0.5 \mathrm{mg} / \mathrm{kg})$ and valsartan $(0.5 \mathrm{mg} / \mathrm{kg})$ orally on renal IL-1 $\beta$, malondialdehyde (MDA) and glutathione (GSH) in renal hypertensive rats. Values with different capital letters are significantly different $(\mathrm{p}<0.05)$

\section{DISCUSSION}

In the current study, a significant increase in mean arterial blood pressure (MABP) was found in control renal hypertensive rats as compared to normal group. This $\uparrow$ in MABP can be explained by that angiotensin II which produces both direct vasoconstriction and adrenal aldosterone secretion which promote sodium reabsorption with expansion of extracellular fluid $(\mathrm{ECF})$ volume ${ }^{[19]}$. It also causes inflammation in the blood vessels which triggers a series of pathologic changes resulting in endothelial dysfunction, vascular growth, and remodeling with subsequent arterial wall stiffness which plays an important cause of hypertension ${ }^{[6]}$.

The result of the present work revealed that renal hypertensive rats treated by candesartan, olmesartan, telmisartan, and valsartan showed significant reduction in MABP compared to control renal hypertensive group. Even though no significant differences were noticed between the groups while, valsartan showed better hypotensive effect more than other ARBs. The antihypertensive effect of ARBs is mainly mediated through blocking the action of angiotensin II on angiotensin II receptor type 1 (AT1) ${ }^{[20]}$. Regarding the hypotensive effects of ARBs the result of the present work is in accordance with those of Jun et al ${ }^{[21]}$ who reported that olmesartan and candesartan cause over-expression of ACE2 that increase the level of Ang-(1-7) which exerts direct vasodilatory effects via stimulating bradykinin and NO release. Additionally, Liu et al. [22] indicates that ARBs appear to provide their beneficial antihypertensive effects not only through AT1 antagonism and down-regulation of AT1 expression but also through up-regulation of AT2 receptors. The greater hypotensive effect of valsartan was studied by Schiffrin and colleagues ${ }^{[23]}$ who compared the effect of various ARBs (candesartan, olmesartan, irbesartan, telmisartan and valsartan) in patients with essential hypertension. The previous authors suggested that valsartan increased significantly serum NO that improves structural and functional properties of small resistant arteries in patients with essential hypertension.

The result of the present work demonstrated a significant increase in heart rate in control renal hypertensive rats and administration of candesartan and telmisartan produced significant reduction in heart rate with insignificant difference in olmesartan and valsartan treated group in relation to control group.

As shown from the result of the present study, administration of telmisartan and candesartan produced cardio protective effect manifested by significant reduction in the heart weight with greater effect of telmisartan over candesartan. Coinciding with these results are those of Galzerano et al. ${ }^{[24]}$ who compared the effect of administration of telmisartan with hydrochlorothiazide on left ventricular mass in mild to moderate hypertensive patients. They found that telmisartan $80 \mathrm{mg}$ significantly reduced SBP, DBP and left ventricular mass index after 12 
months treatment as compared to hydrochlorothiazide. In the same context, Stéphanie et al. ${ }^{[25]}$ reported that candesartan $(0.1 \mathrm{mg} / \mathrm{kg} /$ day $)$ for 4 weeks in spontaneously hypertensive rat effectively reduced the left ventricular weight/body weight $(\mathrm{LVW} / \mathrm{BW})$ ratio to the same level in normotensive animal.

Regarding the effect of candesartan, olmesartan, telmisartan, and valsartan on renal hypertensive rats the current results showed a significant improvement in cardiac fibrosis in relation to control. Comparing the effect of these drugs, it was found that telmisartan and candesartan had a greater cardioprotective effect than that of olmesartan and valsartan. Makoto et al. ${ }^{[26]}$ demonstrated that telmisartan causes reduction in cardiac fibrotic ratio compared to control renovascular hypertensive rats. Concerning valsartan, Akira et al. ${ }^{[27]}$ demonstrated that $1 \mathrm{mg} / \mathrm{kg}$ administration of valsartan for 3 weeks significantly inhibits ventricular interstitial fibrosis in spontaneously hypertensive rats (SHR). The role of Ang II as a profibrotic factor had been studied in many studies since it plays an essential role in the pathogenesis of cardiovascular disease via effects that extend beyond blood pressure ${ }^{[28]}$.

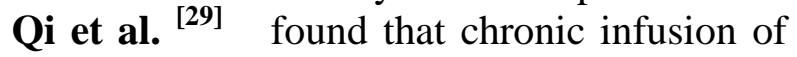
mice with Ang II results in blood pressure elevation, inflammatory cells infiltration into myocardium, and cardiac fibrosis with increased expression of focal adhesion kinases (FAK), integrins, and extracellular matrix proteins ${ }^{[30]}$. Ang II acts also as transforming growth factor that regulates cell proliferation, hypertrophy, and apoptosis ${ }^{[31]}$.

The difference between ARBs cardioprotective effect inspite of the same reduction in blood pressure is a matter of interest. The action of Ang II may be inhibited by a variety of ARBs, but their differences regarding protective effect do not seem to be related only to AT1receptor binding affinity to but also in the presence of other mechanism of action [32]. Regarding cardioprotective ffect of telmisartan, it was found that in myocardial infarction model (MI), telmisartan at therapeutic doses inhibits cardiac remodeling by reducing hypertrophy and fibrosis of cardiomyocytes through an anti-inflammatory effect and peroxisome proliferators-activated receptor gamma (PPAR $\gamma$ ) activation ${ }^{[33]}$. It is well known that PPAR $\gamma$ plays an important role in differentiation of adipocyte, homeostasis of glucose and inflammation ${ }^{[34]}$. It also inhibits the various inflammatory cytokines expression by preventing the activation of transcription factors in the cardiovascular system [27]. The cardioprotective effect of candesartan was studied by Chen et al. [35] who found that candesartan reduced cardiac hypertrophy and remodeling more than that of hydralazine in spite of hydralazine greater antihypertensive effect in spontaneously hypertensive rats by reducing cardiac calcineurin activity which contributes to (AT1) receptor-mediated cardiac hypertrophy and fibrosis. Another mechanism explains candesartan effect on cardiac fibrosis and hypertrophy is its inhibition of mechanical stress [36] which activates AT1 receptor through an angiotensin II-independent mechanism leads to activation of extracellular signal-regulated kinases and increasing phosphoinositide production which finally induces cardiac hypertrophy ${ }^{[37]}$. Regarding inflammatory markers, the result of the present study revealed that the serum level of tumor necrosis factor (TNF $\alpha)$ and the cardiac level of IL-1 $\beta$ were significantly increased in renal hypertensive rats. In the present work telmisartan and candesartan produced additional cardioprotective effects by attenuating these inflammatory markers in relation to control. Therefore, we hypothesized that the protective effects of telmisartan and candesartan with the greater effect of telmisartan may be attributed, at least in part, to the reduction of the inflammatory response via the inhibition of pro-inflammatory cytokines. The currently reported anti-inflammatory effect of telmisartan is in agreement with that of Kubota et al. [38], who reported that telmisartan protected against experimental autoimmune myocarditis, partly by suppressing myocardial expression of inflammatory cytokines (IL-6 and TNF $\alpha$ ) and nicotinamide adenine dinucleotide phosphate (NADPH) oxidase. Cytokines represent a large signaling proteins group that are 
produced and secreted by the immune system and regulate different biological processes including inflammation, immunity and hematopoiesis [39] ANG II increases the synthesis of several cytokines like TNF- $\alpha$ and IL-1B and stimulates chemokine monocyte chemoattractant protein-1 and nuclear factor$\kappa \mathrm{B}^{[40]}$.

Concerning index of glomerulosclerosis, the results of the present study demonstrated that olmesartan and valsartan showed renoprotective effect manifested by significant improvement of glomerulosclerosis in relation to control. However, olmesartan showed higher renoprotective effect than that of valsartan. In our study hypertension was associated with increase cardiac and renal levels of malondialdehyde (MDA) and decrease levels of glutathione (GSH) in renal hypertensive rats and as revealed by the results of the present study candesartan, olmesartan and telmisartan significantly decreased the cardiac level of MDA compared to control though they had insignificant effect on cardiac GSH. Accordingly, we hypothesized that the renoprotective effect of ARBs may be attributed, at least in part, to the oxidative stress reduction. The result of the present work confirmed that olmesartan and valsartan showed significant improvement in the renal level of MDA and GSH as compared to control. Meanwhile, candesartan and telmisartan showed significant effect only on renal MDA which is lower than that of other two groups. ROS also plays a role in progression of renal disease and endothelial dysfunction as they act as second messengers for several transcription factors as nuclear factor- $\kappa \mathrm{B}(\mathrm{NF}-\kappa \mathrm{B})$, which is involved in renal inflammation and hypertrophy [35] The renoprotective effect of olmesartan is mainly due to its antioxidant activity which is mediated by inhibition of NADPH oxidase [41]. In addition, olmesartan acts on local RAAS reducing expression of important chemokines involved in progression of renal fibrosis ${ }^{[42]}$.

\section{CONCLUSION}

The results of the current study clarify the role of oxidative stress and inflammatory cytokines in cardiac and renal complications of hypertension. Furthermore, telmisartan and candesartan show better cardioprotection while olmesartan and valsartan show better renoprotection in renal hypertensive rats. Further experimental and clinical studies are required to confirm the results of the present work, telmisartan and candesartan are recommended if hypertension is associated with prominent cardiac affect while olmesaran and valsartan are recommended if renal complications predominate.

\section{REFERENCES}

1) Brook RD, Appel LJ, Rubenfire M, Ogedegbe G, Bisognano JD, Elliot WJ, et al. Beyond medications and diet: alternative approaches to lowering blood pressure: a scientific statement from the American Heart Association.Hypertension.2013; 61: 1360138.

2) Manotham K, Tanaka T, Matsumoto $M$, Ohse $\mathbf{T}$, Inagi $\mathbf{R}$ Miyata $T$, et al. Transdifferentiation of cultured tubular cells induced by hypoxia. Kidney Int. 2011; 65: 871-880.

3) Kimura L, Angeli CB, Auricchio MT, Fernandes GR, Pereira AC, Vicente J, et al. Multilocus family-based association analysis of seven candidate polymorphisms with essential hypertension in an Africanderived semi-isolated Brazilian population. Int J Hypertens. 2012; 2012: 859219.

4) Hiura Y, Tabara Y, Kokubo Y, Okamura T, Miki T, Tomoike $H$, et al. A genomewide association study of hypertensionrelated phenotypes in a Japanese population. Circ J. 2010; 74: 2353-2359.

5) Houghton BL, Huang C, Johns EJ. Influence of dietary sodium on the blood pressure and renal sympathetic nerve activity responses to intra cerebroventricular angiotensin II and angiotensin III in anaesthetized rats. Exp Physiol. 2010; 95:282-295.

6) Hasegawa H, Takano H, Narumi H, et al. "Effects of telmisartan and losartan on cardiovascular protection in Japanese hypertensive patients," Hypertension Research. 2011, 34(11): 1179-1184.

7) Moore KJ, Tabas I. Macrophages in the pathogenesis of atherosclerosis. Cell. 2011; 145(3):341-55.

8) Fu M, Zhou J, Xu J, Zhu H, Liao J, Cui X, et al. Olmesartan attenuates cardiac 
hypertrophy and improves cardiac diastolic function in spontaneously hypertensive rats through inhibition of calcineurin pathway. Mar. 2014; 63(3):218-26.

9) Calhoun DA, Jones D, Textor S, et al. Resistant hypertension: diagnosis, evaluation, and treatment. A scientific statement from the American Heart Association Professional Education Committee of the Council for High Blood Pressure Research. Hypertension. 2008; 51(6):1403-1419.

10) Xin Lu, I Yan-Wen, Bi I, Ke-Biao ChenII. Olmesartan restores the protective effect of remote ischemic perconditioning against myocardial ischemia/reperfusion injury in spontaneously hypertensive rats. Clinics (Sao Paulo). 2015; 70(7): 500-507.

11) Go AS, Mozaffarian D, Roger VL, Benjamin EJ, Berry JD, Blaha MJ, et al. Executive summary: heart disease and stroke statistics-2014 update: a report from the American Heart Association. Circulation. 2013; 127: e6-e245.

12) Kamiyama E, Yoshigae $\mathbf{Y}$, Kasuya A, Takei M, Kurihara A, Ikeda, T. "Inhibitory Effects of Angiotensin Receptor Blockers on CYP2C9 Activity in Human Liver Microsomes". Drug Metabolism and Pharmacokinetics. 2007; 22 (4): 267-275.

13) Brousil JA, Burke JM. "Olmesartan Medoxomil: An Angiotensin II-Receptor Blocker". Clinical Therapeutics. 2013; 25 (4): 1041-1055.

14) Miura S, Kiya Y, Kanasawa T, Imaizumi S, Fujino M, Matsuo Y et al. "Differential Bonding Interactions of Inverse Agonists of Angiotensin II Type 1 Receptor in Stabilizing the Inactive State". Journal of Molecular Endocriniology. 2010; 22 (1): 139-146.

15) Smith N J, Luttrell L M. Signal switching, crosstalk, and arrestin scaffolds: novel $G$ protein-coupled receptor signaling in cardiovascular disease. Hypertension. 2011; 48:173-179.

16) Watanabe $\mathbf{T}$, Kusuhara $\mathbf{H}$, Debori $\mathbf{Y}$, Maeda K, Kondo T, Nakayama $H$, et al. Prediction of the overall renaltubular secretion and hepatic clearance of anionic drugs and a renal drug-druginteraction involving organic anion transporter 3 in humans by in vitro uptake experiments. Drug Metab Dispos. 2011; 39:1031-108.
17) Nangaku M, Miyata T, Sada T, Mizuno M, Inagi ,R, Ueda $\mathbf{Y}$, et al. Anti-hypertensive agents inhibit in vivo the formation of advanced glycation end products and improve renal damage in a type 2 diabetic nephropathy rat model. J. Am. Soc Nephrol. 2003; 14: 1212-1222.

18) Armitage $\mathbf{P}$ and Berry G. Statistical methods in medical research, $3^{\text {rd }}$ edition; Blackwell Scientific Publications, Oxford. London. 1994; pp 620.

19) Zouein Fouad A, De Castro Brás Lisandra E, Da Costa Danielle V, Lindsey Merry L, Kurdi Mazen, Booz George W. "Heart Failure with Preserved Ejection. EMBO Rep. 2013; 9:179-186.

20) Klingbeil AU, John S, Schneider MP Jacobi J, Weidinger G, Schmieder RE. AT1-receptor blockade improves augmentation index: a double-blind, randomized, controlled study. J. Hypertens. 2002; 20(12): 2323.

21) Jun Agatai , Nobuyuki,ura I, Hideaki yoshidai , Yasuyuki shinshi, Haruki sasaki , Masaya hyakkokuu . Olmesartan Is an Angiotensin II Receptor Blocker with an Inhibitory Effect on Angiotensin-Converting Enzyme. Hypertens Res. 2006; 29(11).

22) Liu G, Hitomi H, Hosomi N, et al. "Prorenin induces vascular smooth muscle cell proliferation and hypertrophy via epidermal growth factor receptor-mediated extracellular signal-regulated kinase and Akt activation pathway. Journal of Hypertension. 2013; 29(4): 696-705.

23) Schiffrin EL, Park JB, Intengan H D, Touyz RM. Correction of arterial structure and endothelial dysfunction in human essential hypertension by the angiotensin receptor antagonist losartan. Circulation. (2008); 101(14):1653-9.

24) Galzerano D, Di Michele S, Paolisso G, et al. "A multicenter, randomized study of telmisartan vs. carvedilol for prevention of atrial fibrillation recurrence in hypertensive patients," Journal of Renin-AngiotensinAldosterone System. Circ J .2014; 74: 23532359.

25) Stéphanie C Choisy, Shang-Jin Kim,Jules C Hancox,Sandra A. Jones, Andrew F James. Effects of candesartan, an angiotensin II receptor type I blocker, on atrial 
remodeling in spontaneously hypertensive rats. Physiol Rep. 2015; 3(1): e12274.

26) Makoto Kawai, Kenichi Hongo, Kimiaki Komukai, Satoshi Morimoto, Makoto Nagai, Shingo Seki et al. Telmisartan predominantly suppresses cardiac fibrosis، rather than hypertrophy, in renovascular hypertensive rats. Hypertension Research .2009; 32: 604-610.

27) Akira Akashiba, Hidehiko Ono, Yuko Ono, Toshihiko Ishimitsu. Valsartan improves 1NAME-exacerbated cardiac fibrosis with TGF- $\beta$ inhibition and apoptosis induction in spontaneously hypertensive rats. Department of Hypertension and Cardiorenal Medicine. 2008; 880:321-0293.

28) Bakris G, Burgess E, Weir M, Davidai G., Koval S. "Telmisartan is more effective than losartan in reducing proteinuria in patients with diabetic nephropathy," Kidney International. 2008; 74(3) 364-369.

29) Qi G, Jia L, Li Y, et al. Angiotensin II infusion-induced inflammation, monocytic fibroblast precursor infiltration, and cardiac fibrosis are pressure dependent,". Cardiovascular Toxicology. 2011; 11(2): 157-167.

30) Gul R, Shawl A I, Kim SH, Kim UH. "Cooperative interaction between reactive oxygen species and $\mathrm{Ca} 2+$ signals contributes to angiotensin II-induced hypertrophy in adult rat cardiomyocytes,". American Journal of Physiology-Heart and Circulatory Physiology. 2012; 302 4): H901-H909.

31) Kumar R, Thomas CM, Yong QC, Chen W, Baker KM. The intracrine reninangiotensin system. Clin Sci (Lond).2012; 123(5):273-284.

32) Ferreira-Junior NC, Fedoce AG, Alves FH, Correa FM, Resstel LB. Medial prefrontal cortex endocannabinoid system modulates baroreflex activity through CB (1) receptors. Am J Physiol Regul Integr Comp Physiol.2012; 302(7):876-885.

33) Keizo Matsushita, Hai-Chun Yang, Manu Mysore1, Jianyong Zhong, Yu Shyr, LiJun Maet al. Systems Effects of combination PPAR $\gamma$ agonist and angiotensin receptor blocker on glomerulosclerosis Laboratory Investigation .2016; 96: 602-609.
34) Desch M, Schubert T, Schreiber A, et al. PPARgamma-dependent regulation of adenylate cyclase 6 amplifies the stimulatory effect of cAMP on renin gene expression.Mol indocrinol.2010; 24:2139-2151.

35) Chen S, Ge Y, Si J, et al. Candesartan suppresses chronic renal inflammation by a novel antioxidant action independent of AT1R blockade. Kidney Int.2008; 74: 11281138

36) Arumugam S, Thandavarayan RA,Veeraveedu PT,Nakamura T, Arozal W, Sari FR et al. Beneficial effects of edaravone, a novel antioxidant, in rats with dilated cardiomyopathy. J Cell Mol Med. 2012; 16:2176-85.

37) Stacher E, Graham BB, Hunt JM, Gandjeva A, Groshong SD, McLaughlin VV, et al. Modern age pathology of pulmonary arterial hypertension. Am J Respir Crit Care Med. 2012; 186:261-272.

38) Kubota M, Shimizu M, Sakai H, et al. "Renin-angiotensin system inhibitors suppress azoxymethane-induced colonic preneoplastic lesions in C57BL/KsJ-db/db obese mice,". Biochemical and Biophysical Research communications.2011; 410(1): 108-113.

39) Tamosiuniene R, Nicolls MR. Regulatory T cells and pulmonary hypertension. Trends Cardiovasc Med.2012; 21:166-171.

40) Liu CX, Hu Q, Wang Y, Zhang W, Ma ZY, Feng JB, et al. Angioten-sin-Converting Enzyme 2 Overexpression Remarkably Ameliorated Glomerular Injury in a Rat Model of Diabetic Nephropathy: Comparison with ACE Inhibition. Mol Med.in press. Neurourol Urodyn. 2010; 33(3):350-7.

41) Kim HJ, Sato T, Rodriguez-Iturbe B, Vaziri ND. Role of intrarenal angiotensin system 448 activation, oxidative stress, inflammation, and impaired nuclear factorerythroid-related factor 2 activity in the progression of focal glomerulosclerosis. $\mathrm{J}$ Pharmacol Exp Ther .2011;337:583-90.

42) Brezniceanu ML, Li uF, Wei CC, et al. Catalase overexpression attenuates angiotensinogen expression and apoptosis in diabetic mice. Kidney Int.2007; 71: 912-923. 